\title{
RAZVOJ KONCEPTA NEOPRAVDANOG OBOGAĆENJA U RECEPCIJI RIMSKOG PRAVA
}

Sažetak:

Autor u radu analizira razvoj neopravdanog obogaćenja, odnosno stjecanja bez osnove, kao općeg i samostalnog izvora obveze. Iako takav koncept nije postojao u rimskom pravu, određene rimske tužbe uvelike su korištene u formativnom razdoblju srednjovjekovne civilistike i kanonistike, kao i u naknadnoj recepciji rimskog prava u ovom kontekstu. Na tom temelju i suvremene teorijske analize te sudska praksa nerijetko posežu za rimskom pravnom terminologijom u kontekstu neopravdanog obogaćenja (kondikcijski i verzijski zahtjevi, condictio, actio de in rem verso, itd.). Analizom se nastoji dati doprinos potpunijem i ispravnijem razumijevanju povezanosti rimskih tužbi s oblikovanjem koncepta neopravdanog obogaćenja, a samim time $i$ njihovoj relevantnosti u suvremenom kontekstu. Radi toga najprije se obraduje opći razvoj u srednjovjekovlju, a nakon toga dvije temeljne novovjekovne razvojne tendencije, jedna vezana za francusko pravo u kojemu je u razvoju koncepta neopravdanog obogaćenja važniju ulogu imao verzijski zahtjev (actio de in rem verso) te druga vezana za njemačko pravo, koja počiva na rimskim kondikcijskim zahtjevima (condictiones). Uz to, analiziraju se $i$ engleski common law te ugarsko privatno pravo kao primjeri sustava koji izvorno nisu bili snažnije povezani s rimskim pravom u području koje je predmet analize, ali su se naknadno reformirali pod njegovim utjecajem, i to prvenstveno uz pomoć sustava snažnije oblikovanih na temelju rimskih kondikcijskih zahtjeva. Naposljetku se donose zaključci vezani za opću prisutnost rimskog prava u razvoju koncepta neopravdanog obogaćenja i u njegovim suvremenim inačicama te za optimalnost sustava koji autentičnije počivaju na rimskim izvorima.

Ključne riječi: $\quad$ neopravdano obogaćenje, stjecanje bez osnove, condictio, actio de in rem verso, rimsko pravo, recepcija rimskog prava 


\section{UVOD**}

Jedan od središnjih problema vezan za neopravdano obogaćenje, odnosno stjecanje bez osnove, ${ }^{1}$ jest njegova uspostava i formulacija kao općeg i samostalnog izvora obveza. Naime, iako je rimsko pravo bez ikakve sumnje temelj i glavni terminološki i konceptualni okvir za navedeno područje, ipak ono ni u jednom razdoblju svojeg postojanja nije poznavalo opći i apstraktni koncept neopravdanog obogaćenja kao samostalnog izvora obveze. ${ }^{2}$ Uostalom, to je u skladu s nesklonošću rimskih pravnika prema apstraktnim konceptima te načelnoj usmjerenosti rimskog prava na pitanja konkretne pravne zaštite. ${ }^{3} \mathrm{U}$ području koje se u naknadnom razvoju počelo povezivati s konceptom neopravdanog obogaćenja najvažnije rimske tužbe bile su klasična condictio, odnosno različite condictiones Justinijanova prava, a uz njih i actio de in rem verso te u određenoj mjeri actio negotiorum gestorum. ${ }^{4}$ Kako će se vidjeti iz analize koja slijedi, kondikcijski zahtjevi bili su najvažniji element pri oblikovanju koncepta neopravdanog obogaćenja.

Što se tiče same kondikcijske zaštite, nesporno je kako je ona u svakom razdoblju svojeg postojanja u rimskom pravu imala određeni metajuridički sadržaj, koji je dijelom upućivao na raison d'être u pozadini pojedinih tužbi, i koji je u određenoj mjeri mogao doprinijeti oblikovanju koncepta neopravdanog obogaćenja kao općeg i samostalnog temelja obveze. Tako se u najstarijem obliku kondikcijske zaštite, legisakciji per condictionem, to očitovalo u oblikovanju njezine primjene s obzirom na rimske koncepte vezane za fides i ono što se smatralo pravednim, iustum, te na određene analogne postupke u drugim pravnim područjima. ${ }^{5} \mathrm{U}$ klasičnoj condictio u sklopu formularnog postupka očitovao se nastavak takvog interpretativnog koncipiranja kondikcijske zaštite, uz referiranje na određene stoičke koncepte pravičnosti. ${ }^{6} \mathrm{Na}-$ posljetku, postklasični koncept pravičnosti (aequitas) ostvario je snažan utjecaj na koncepciju kondikcijske zaštite u Justinijanovoj kodifikaciji. ${ }^{7}$

Razvoj u rimskom pravu bio je temelj za nastanak neopravdanog obogaćenja kao općeg i samostalnog izvora obveze koji se dogodio u europskoj srednjovjekovnoj civilističkoj i kanoni-

** Ovaj rad je nastao u okviru znanstvenog projekta Novi hrvatski pravni sustav Pravnog fakulteta Sveučilišta u Zagrebu za 2017.

1 U ovom radu koristi se termin neopravdano obogaćenje kao najprikladniji prijevod postojećih termina u pravnim sustavima čiji je povijesni razvoj predmet dijela analize (enrichissement sans cause, arrichimento senza causa, ungerechtfertigte Bereicherung, unjustified enrichment). Više o terminologiji u tom području u Held, H.-R., Neki problemi suvremenog uređenja stjecanja bez osnove, Hrvatska pravna revija 13 (2015), str. 13. sqq., str. 14. sq.

2 Za više vidjeti Zimmerman, R., The Law of Obligations, Cape Town, 1992., str. 834. sqq., s iscrpnim uputama na izvore i daljnju literaturu.

3 Za više o apstraktnosti u rimskom pravu vidjeti Schulz, F., Prinzipien des römischen Rechts, Berlin, 2003., str. 27. sqq.

4 Među poznate kondikcijske zahtjeve Justinijanova prava korištene u srednjovjekovnoj obradi i naknadnoj recepciji spadaju condictio indebiti, condictio causa dana causa non secuta, condictio ob turpem vel iniustam causam, condictio sine causa, condictio ob causam finitam itd. (cf. Zimmerman, op. cit. u bilj. 2, str. 857. sqq.). Za actio de in rem verso vidjeti ibid. str. 878. sqq., a za actio negotiorum gestorum ibid. str. 875. sqq.

5 Za više vidjeti Held, H.-R., Podrijetlo postupka legis actio per condictionem, Zbornik Pravnog fakulteta u Zagrebu 67, 2 (2017), str. 197. sqq.

6 Za više vidjeti Wollschläger, C., Das stoische Bereicherungsverbot in der römischen Rechtswissenschaft, u: Behrends, O. et al. (ur.), Römisches Recht in der europäischen Tradition, Ebelsbach, 1985., str. 41. sqq.

7 Za postklasični koncept pravičnosti (aequitas) i njegov utjecaj na pravo cf. Petrak, M., Inter aequitatem iusque interpositam interpretationem nobis solis et oportet et licet inspicere. Konstantinovo shvaćanje pravednosti u suprotnosti s klasičnim rimskim pravom, Latina et graeca, nova serija 24 (2014), str. 39. sqq. 
stičkoj doktrini te u naknadnom razvoju. Pritom su nastale dvije različite razvojne tendencije. Jedna je vezana za francusko pravo i srodna uređenja, u kojima važniju ulogu ima actio de in rem verso, dok je od kondikcija istaknuta jedino condictio indebiti. Druga je vezana za njemačko pravo i njemu srodne sustave, a u tim uređenjima snažnije je prisutan cjelokupni rimski kondikcijski sustav. Nakon prikaza nastanka i razvoja tih sustava, analizira se i englesko common law uređenje te ugarsko privatno pravo, to jest privatno pravo Tripartita, u svojem važenju u dijelovima Habsburške Monarhije te u Kraljevini SHS, odnosno Kraljevini Jugoslaviji, uključujući i određene hrvatske krajeve. U navedenim uređenjima se unatoč izostanku izvorne snažnije veze s rimskim pravom u ovom području u tijeku razvoja može primijetiti njegov naknadni utjecaj. Navedena analiza na taj način nastoji dati temeljni pregled najvažnijih smjerova razvoja uređenja neopravdanog obogaćenja u europskim obveznopravnim sustavima. ${ }^{8}$ Time se nadamo doprinijeti potpunijem i ispravnijem razumijevanju prisutnosti različitih rimskih tužbi u razvoju koncepta neopravdanog obogaćenja, kao i njihovoj terminološkoj i konceptualnoj prisutnosti u suvremenom pravu. ${ }^{9}$

\section{OPĆI RAZVOJ U CIVILISTIČKOJ I KANONISTIČKOJ DOKTRINI TE U RECEPCIJI RIMSKOG PRAVA}

Proces oblikovanja neopravdanog obogaćenja kao općeg i samostalnog izvora obveze u srednjovjekovnoj obradi i naknadnoj recepciji rimskoga prava može se analizirati s dva razvojna aspekta. Jedan se odnosi na konkretizaciju općeg pravila o zabrani obogaćenja jedne osobe na teret druge iz rimskog prava (rimsko pravno načelo vezano za fragmente D. 12, 6 , 14 (Pomp. 21 ad Sab.): Nam hoc natura aequum est neminem cum alterius detrimento fieri locupletiorem. ${ }^{10}$ i D. 50, 17, 206 (Pomp. 9 ex var. lect.): Iure naturae aequum est neminem cum alterius detrimento et iniuria fieri locupletiorem. ${ }^{11}$ ), a drugi na primjenu pojedinih tužbi iz rimskog prava u ovom području.

Važan doprinos ovoj materiji dao je Jan Hallebeek. ${ }^{12}$ Taj autor smatra kako se načelo o zabrani obogaćenja na teret drugog u srednjovjekovnom kontekstu razvilo najprije u okvirima

8 Za opći pregled uređenja u europskim zemljama vidjeti Bar, C. von; Swann, S. (ur.), Unjustified Enrichment (PEL Unj.Enr.), München, 2010., str. 93. sqq. Za više o uređenju posebno u istočnim europskim zemljama vidjeti Łętowska, E., Unjust Enrichment in Eastern European Countries, u: Caemmerer, E. von; Schlechtriem, P. (ur.), International Encyclopedia of Comparative Law 10, Tübingen, 2007., poglavlje 4, str. 3. sqq. Valja napomenuti kako nizozemski građanski zakonik, iako izvorno temeljen na francuskom uzoru, danas ipak sadrži opće pravilo kojim uređuje neopravdano obogaćenje u čl. 6:212. Više o nizozemskom uređenju i njegovoj povijesti u Snijders, W., From Pomponius to Article 6:212 Dutch Civil Code-The Vicissitudes of a Tradition, European Review of Private Law 14, 3 (2006.), str. 391. sqq.; Hartkamp, A. S., Unjust Enrichment alongside Contracts and Torts, u: Schrage, E. (ur.), Unjust Enrichment, Berlin, 1999., str. 25. sqq.; Schrage, E., The Law of Restitution: The History of Dutch Legislation, u: Schrage, E. (ur.), Unjust Enrichment, Berlin, 1999., str. 323. sqq.; Schrage, E., Unjustified enrichment. Recent Dutch developments from a comparative and historical perspective, Netherlands International Law Review 46, 1 (1999), str. 57. sqq.

9 Uz određene relevantne europske pravne sustave čiji se razvoj analizira u ovom radu, za prisutnost kondikcijskih i verzijskih zahtjeva u hrvatskoj teoriji i sudskoj praksi više u Held, H.-R., Kondikcijski i verzijski zahtjevi de iure condito, Pravo u gospodarstvu 54, 6 (2015), str. 1343. sqq.

10 U prijevodu: Po prirodi je pravično da se nitko ne obogati na teret drugoga.

11 U prijevodu: Po prirodnom pravu je pravično da se nitko ne obogati protupravno na teret drugoga.

12 Posebno u Hallebeek, J., Developments in Mediaeval Law, u: Schrage, E. (ur.), Unjust Enrichment, Berlin 1999., str. 59. sqq., $\mathrm{u}$ nešto suženom obliku u Hallebeek, J., The condiction as enrichment action in twelfth and thirteenth century legal scholarship, 
teologije i kanonskog prava. ${ }^{13} \mathrm{U}$ tom smislu navedeno pravilo proizlazilo bi iz zabrane krađe, koja je biblijski izražena kao pravilo non furtum facies. ${ }^{14} \mathrm{Na}$ tom temelju je u teologiji svetog Augustina bilo ustanovljeno pravilo prema kojem nije moguće odrješenje od grijeha ako počinitelj nije izvršio restituciju koja je vezana za taj grijeh. ${ }^{15}$ Ovo pravilo je našlo svoj konkretni izraz i u srednjovjekovnom kanonskom pravu, što se može vidjeti u zbirkama Decretum Gratiani iz prve polovine 12. st. i Liber Sextus iz $1298 .^{16}$

U teološkom kontekstu, sveti Toma Akvinski je nadovezano na navedeno u 13. st. razvio posebnu restitucijsku teoriju. ${ }^{17} \mathrm{U}$ drugom dijelu druge knjige njegova kapitalnog djela Summa Theologica, questio 62 je tako u potpunosti posvećena restituciji. ${ }^{18}$ Articulus 6 navedene questio bavi se obvezom povrata te navodi da ona postoji dok god stvar jedne osobe postoji u imovini druge. ${ }^{19} \mathrm{U}$ navedenom tekstu spominje se iustitia commutativa, komutativna pravednost, što je očita referenca na Aristotelove koncepte pravednosti, koji se dovode u vezu i s rimskim pravom. ${ }^{20} \mathrm{Na}$ taj način je u okvirima srednjovjekovne teološke misli i kanonskog prava oblikovana posebna restitucijska teorija, koja se zasnivala na Svetom pismu i Aristotelovim konceptima pravednosti.

U srednjovjekovnoj civilističkoj teoriji također se počinje razvijati srodno restitucijsko načelo, ali u užim okvirima rimske pravne tradicije. ${ }^{21}$ Tu je riječ o preuzimanju već spomenutih Pomponijevih fragmenata iz Digesta. Oni ustanovljuju pravilo prema kojem je obogaćenje jedne osobe na teret druge u suprotnosti prirodi i prirodnom pravu. Pritom je fragment D. 50, 17, 206 (Pomp. 9 ex var. lect.) još u Justinijanovoj kodifikaciji stavljen na rang općeg načela, s obzirom na to da je bio svrstan pod titul De diversis regulis iuris antiqui. S druge strane, D. 12, 6, 14 (Pomp. 21 ad Sab.) se pojavljuje u konkretnim okvirima kondikcije kod indebiti solutio, i to kao iznimka od obveze povrata (neposredno prije ovog fragmenta, u D. 12, 6, 13, 1 (Paul.

Tijdschrift voor Rechtsgeschiedenis 63 (1995), str. 263. sqq., te Hallebeek, J., Unjust enrichment as a source of obligation. The genesis of a legal concept in the European ius commune, Restitution Law Review 10 (2002), str. 92. sqq.

13 Cf. Hallebeek, op. cit. u bilj. 12 (1995), str. 264.; Hallebeek, op. cit. u bilj. 12 (1999), str. 59. sq. i Hallebeek, op. cit. u bilj. 12 (2002), str. 93. i 97.

14 Vidjeti EXOD. 20, 15.

15 Tako sv. Augustin u EPIST. 153, 20 navodi sljedeće: Si enim res aliena, propter quam peccatum est, cum reddi possit, non redditur, non agitur poenitentia, sed fingitur: si autem veraciter agitur, non remittetur peccatum, nisi restituatur ablatum; sed, ut dixi, cum restitui potest (u prijevodu: Ako dakle tuđa stvar, zbog koje je zgriješeno, nije vraćena iako je njezino vraćanje moguće, nije izvršeno pokajanje, nego je fingirano; ako se pak iskreno izvrši pokajanje, ne odrješuje se grijeh ako se ne izvrši povrat; ali, kako sam rekao, ako je povrat moguć).

Vidjeti Decretum Gratiani C. XIV, q. VI, c. I, gdje je na samom početku preuzeto praktički identično pravilo koje iznosi sv. Augustin u neposredno prethodno citiranom odlomku, te Liber Sextus V, 13, 4, gdje se nalazi regula iuris koja glasi: Peccatum non dimittitur, nisi restituatur ablatum (u prijevodu: Grijeh se ne odrješuje, ako nije obavljena restitucija) (cf. Hallebeek, op. cit. u bilj. 12 (1999), str. 60, bilj. 3). Više o zbirci Decretum Gratiani u Rambaud-Buhot, J., Gratian, Decretum of (Concordia discordantium canonum), u: Halfmann, J. (ur.), New Catholic Encyclopedia 6, Detroit, 2003., str. 420.-422, a o Liber Sextus u Boyle, L. E., Liber Sextus, u: Halfmann, J. (ur.), New Catholic Encyclopedia 8, Detroit, 2003., str. 536.

17 Cf. Hallebeek, op. cit. u bilj. 12 (2002), str. 97.

18 Vidjeti SUMMA II-II, q. 62. Za više o pravu općenito u djelu sv. Tome Akvinskog vidjeti Obiwulu, A., Tractatus de legibus in 13th Century Scholasticism, Münster, 2003., str. 178. sqq., s uputama na daljnju literaturu. SUMMA II-II, q. 62., art. 6.

21 Tako Hallebeek, op. cit. u bilj. 12 (1995), str. 264. sq.; Hallebeek, op. cit. u bilj. 12 (2002), str. 94. sqq.; te detaljnije u Hallebeek, op. cit. u bilj. 12 (1999), str. 60. sqq. 
10 ad Sab.) nalazi se pravilo prema kojemu pupil nije mogao potraživati natrag zajam koji je vratio nakon doraslosti, a koji je bio dobio za vrijeme nedoraslosti te je zbog toga taj zajam bio nevaljan). Međutim, u glosatorskom razdoblju jedna anonimna predakurzijevska glossa interlinearis na D. 12, 6, 14 (Pomp. 21 ad Sab.) upućuje na to da navedena zabrana obogaćenja na teret drugog ne treba funkcionirati samo kao temelj za nedostupnost tužbe u konkretnom slučaju, već i kao opravdanje za tu tužbu. ${ }^{22}$

Navedene dvije razvojne tendencije, jedna u kanonskopravnom i druga u civilnopravnom području, navodi se, ujedinjuju se u kasnom španjolskom skolasticizmu, odnosno u poznatoj školi iz Salamanke u šesnaestom stoljeću. ${ }^{23}$ Teorijska razrada restitucijskog prava te škole predstavlja temelj za prirodnopravni koncept zabrane obogaćenja jedne osobe na teret druge koji se pojavljuje u djelu Huga Grotiusa (1583.-1645.). ${ }^{24}$ Tek se kod njega navedeni koncept može smatrati samostalnim i općim izvorom obveze.

U svakom slučaju prema navedenome, ključan i temeljni element u razvoju neopravdanog obogaćenja kao općeg i samostalnog izvora obveze pripisuje se srednjovjekovnoj teologiji i kanonistici. Možemo se složiti da je njihov doprinos općem konceptu neopravdanog obogaćenja u europskim privatnopravnim sustavima nesporan. Međutim, smatramo da se kao primaran treba istaknuti upravo utjecaj rimskog prava. To je najprije vidljivo u kontekstu navedenih Pomponijevih sentenci, koje su u srednjovjekovlju figurirale kao vrlo jasna formulacija zabrane obogaćenja na teret drugog. Ne samo da su te sentence očito starije od srednjovjekovnog oblikovanja restitucijske teorije, nego je pritom vidljiv utjecaj rimskog na kanonsko pravo, a ne obrnuto. Tako, primjerice, već spomenuti Liber Sextus sadrži sljedeće načelo u V, 13, 48:

\section{Locupletari non debet aliquis cum alterius iniuria, vel iactura. ${ }^{25}$}

U navedenom se iščitava zabrana obogaćenja na teret drugog sadržajno i formulacijski očito temeljena na spomenutim Pomponijevim sentencama. Zbog toga se može reći da u konceptualnom i strukturalnom smislu neopravdano obogaćenje kao opći i samostalni izvor obveze u bitnome proizlazi iz rimskog prava. Utjecaj srednjovjekovnih teoloških i kanonskopravnih koncepata može se vrjednovati na sličan način kao utjecaj rimskih religioznih predodžbi, stoičke filozofije ili helenističkog i kršćanskog koncepta aequitas na kondikcijsku zaštitu u različitim razdobljima njezina razvoja unutar rimskog prava, što je već naznačeno u uvodu. Drugim riječima, ti koncepti predstavljaju metajuridički sadržaj i opravdanje jednog u bitnome autonomnog privatnopravnog instituta. Kao bitan nov doprinos može se istaknuti vrjednovanje i formulacija neopravdanog obogaćenja kao konceptualno samostalnog izvora obveze.

Osim u pogledu načela zabrane obogaćenja na teret drugog, utjecaj rimskog prava vidljiv je i u pogledu rimskih tužbi koje su se u srednjovjekovnoj i naknadnoj doktrini predlagale u

22 Vidjeti Hallebeek, op. cit. u bilj. 12 (1999), str. 64. sq.

23 Vidjeti Hallebeek, op. cit. u bilj. 12 (2002), str. 97.

24 U tom smislu Feenstra, R., Die ungerechtfertigte Bereicherung in dogmengeschichtlicher Sicht, Ankara Üniversitesi Hukuk Facültesi Dergisi 29 (1972), str. 289. sqq., str. 293., te Hallebeek, op. cit. u bilj. 12 (2002), str. 98. sq. Za više o konceptu neopravdanog obogaćenja kod Grotiusa i njegovu utjecaju na rimsko-nizozemsko pravo vidjeti posebno Feenstra, R., Grotius' Doctrine of Unjust Enrichment as a Source of Obligation: Its Origin and Its Influence in Roman-Dutch Law, u: Schrage, E. (ur.), Unjust Enrichment, Berlin, 1999., str. 197. sqq., s uputama na daljnju literaturu. 
kontekstu neopravdanog obogaćenja in statu nascendi. Tu najprije treba istaknuti condictio. Ta je tužba na temelju tumačenja D. 12, 1, 32 (Cels. 5 dig.), poznatog i kao lex Si et me et Titium, upotrebljavana kao tužba za povrat imovine koju je jedna osoba neutemeljeno stekla na teret druge. ${ }^{26}$ Osim toga, na temelju konstitucije C. 4, 26, 7, 3 (Imp. Diocl. et Maxim.), actio de in rem verso također se počela smatrati općom tužbom kojom se sankcionira obogaćenje jedne osobe na teret druge. Pritom se za nju koristio naziv actio utilis de in rem verso. ${ }^{27} \mathrm{Uz}$ to, glosator Martinus Gosia (cca 1120.-1160.) je na temelju fragmenta D. 3, 5, 5, 5 (Ulp. 10 ad ed.) pokušao ustanoviti actio negotiorum gestorum utilis kao opću tužbu kojom bi se sankcioniralo obogaćenje jedne osobe na teret druge. ${ }^{28}$ Pokušaj ustanovljavanja opće tužbe, utemeljene na konceptu pravednosti, koja pritom ne odgovara u potpunosti izvorima rimskog prava, mogao bi se pripisati Martinovoj sklonosti načelima pravičnosti. ${ }^{29}$ Tomu se usprotivio Bulgarus de Bulgarinis (umro cca 1165.), ${ }^{30}$ kao i ostali glosatori te navedeno rješenje nije bilo prihvaćeno ni u Akurzijevom kapitalnom djelu Glossa Magistralis seu Ordinaria iz sredine 13. st. ${ }^{31}$ Negotiorum gestio je u europskoj pravnoj misli i praksi tako (p)ostala zasebni pravni institut, nevezan usko za stjecanje bez osnove, odnosno neopravdano obogaćenje. .2,33 $^{3}$

U kasnijem razvoju, glede čega se posebno može istaknuti usus modernus pandectarum u 17. i 18. st., prvenstveno se u kontekstu opće tužbe iz neopravdanog obogaćenja spominju actio de in rem verso te condictio. ${ }^{34}$ Međutim, pritom valja istaknuti kako je actio de in rem verso u kontekstu neopravdanog obogaćenja dosta promijenjena u odnosu na svoju izvornu svrhu i karakter. U izvornom obliku ova tužba je sankcionirala obogaćenje koje je stekao pater familias radnjom roba ili sina obitelji, a u postklasičnom pravu i radnjom neke druge osobe te je u svakom slučaju kod te tužbe bila riječ o trostranim pravnim odnosima. Tek se u naknadnom razvoju, točnije u 18. st., izgubila potreba postojanja posrednika u obogaćenju, te je actio de in rem verso postala tužba primjenjiva u dvostranim odnosima. ${ }^{35}$ Što se tiče izmjena u koncepciji ove tužbe u recepciji rimskog prava, valja napomenuti i kako se u određenim slučajevima primjene koje je poznavao usus modernus pandectarum smatralo da actio de in rem verso može

26 Vidjeti Zimmerman, op. cit. u bilj. 2, str. 874.; Hallebeek, op. cit. u bilj. 12 (1995), str. 265.; Hallebeek, op. cit. u bilj. 12 (2002), str. 95. U pravnoj znanosti petnaestog stoljeća za ovu tužbu, osim termina condictio koristio se i termin actio in factum ex aequitate (vidjeti Hallebeek, J., Some remarks concerning the so-called Condictio Iuventiana (D. 12, 1, 32), Revue internationale des droits de l'antiquite, $3^{\text {e }}$ série, tome 32 (1985), str. 247. sqq., str. 265. i Hallebeek, op. cit. u bilj. 12 (2002), str. 96.). Vidjeti Zimmerman, op. cit. u bilj. 2, str. 878. sqq., posebno str. 880. sq., te Hallebeek, op. cit. u bilj. 12 (2002), str. 95. Vidjeti Hallebeek, op. cit. u bilj. 12 (1995), str. 264; Hallebeek, op. cit. u bilj. 12 (1999), str. 66.; Hallebeek, op. cit. u bilj. 12 (2002), str. 95.

29 Za više o tom glosatoru vidjeti Kantorowicz, H.; Buckland, W., Studies in the Glossators of Roman Law, Aalen, 1969., str. 86. sqq. Bulgarus je kao strogi pobornik ius strictum i inače poznat po suprotstavljenosti Martinovim sklonostima pravičnosti. Za više o Bulgaru vidjeti Kantorowicz i Buckland, op. cit. u bilj. 29, str. 68. sqq.

Cf. Feenstra, op. cit. u bilj. 24 (1972), str. 298.; Hallebeek, op. cit. u bilj. 12 (1995), str. 265.; Hallebeek, op. cit. u bilj. 12 (2002), str. 95. Općenito o konceptu neopravdanog obogaćenja kod Akurzija u Coing, H., Zur Lehre von der ungerechtfertigten Bereicherung bei Accursius, ZRG-RA 80 (1963), str. 396. sqq. Za pregled navedenog razvoja vidjeti Zimmerman, op. cit. u bilj. 2, str. 433. sqq., s iscrpnim uputama na izvore i daljnju literaturu.

Martinova teza, inače vezana za Ulpijanov fragment D. 3, 5, 5, 5 (Ulp. 10 ad ed.), ipak jest izvršila određen utjecaj na kasnije teoretičare, kao što su bili Petrus de Bellapertica (cca 1230.-1308.), Cinus de Pistoia (cca 1270.-1337.) i Jacobus Cuiacius (1522.-1590.). Preko Charlesa Dumoulina (1500.-1566.) i Roberta Josepha Pothiera (1699.-1772.), ovaj utjecaj je vidljiv i u francuskom te u nizozemskom građanskom zakoniku. Naime, u njima je graditelju zgrade u dobroj vjeri na tuđem zemljištu dopuštena tužba kojom može zahtijevati obogaćenje koje je stekao vlasnik zemljišta (Feenstra, op. cit. u bilj. 24 (1972), str. 298). 
predstavljati i pravno sredstvo in rem. Drugim riječima, njome se moglo sankcionirati i obogaćenje nastalo u odnosu na stvar, a ne konkretnu osobu, te se onda kao tuženik mogao javiti svakodobni vlasnik stvari. ${ }^{36}$

Međutim, condictio je u svim svojim pojavnostima ipak imala središnji i najvažniji položaj u kontekstu neopravdanog obogaćenja u recepciji rimskog prava. Razlog tomu je najvjerojatnije apstraktnost kao njezina temeljna karakteristika još iz rimskog prava, na temelju koje je bila primjenjiva u raznim okolnostima. ${ }^{37}$ Stoga ne čudi da je još Jacobus de Ravanis (cca 1230.-1296.) na temelju Celzova fragmenta D. 12, 1, 32 (Cels. 5 dig.) uspostavio condictio sine causa ex aequitate kao svojevrsnu opću tužbu. ${ }^{38}$ Različite condictiones iz Justinijanova prava bile su prisutne i u usus modernus pandectarum..$^{39}$ Tako Leyser izrijekom potvrđuje navedeni Ravanisov stav, time što navodi da je na temelju citiranog Celzova fragmenta moguća condictio ili actio utilis de in rem verso. ${ }^{40}$

Može se reći kako je u kontekstu različitih korištenih rimskih tužbi condictio u svim svojim oblicima bila najstarije i najvažnije sredstvo, koje se smatralo najpovezanijim s citiranim Pomponijevim sentencama, odnosno rimskim načelom o zabrani obogaćenja na teret drugog. ${ }^{41}$ Zbog toga bi se stvaranje koncepta neopravdanog obogaćenja moglo promatrati kao inverzija rimskih kondikcija, odnosno ekstrapolacija biti njihove primjene i uzdizanje toga na razinu samostalnog izvora obveze. U tom smislu bi se moglo reći kako su na određeni način pojedini slučajevi primjene klasične condictio, odnosno različite justinijanovske condictiones, konceptualno objedinjene $\mathrm{u}$ jedinstven teorijski pravni institut. Međutim, kako je već napomenuto $u$ uvodu, na temelju analiziranog razvoja u teoriji i praksi ipak su nastala dva bitno različita uređenja na europskom kontinentu. Njihov razvoj, kao i utjecaj rimskog kondikcijskog sustava na neka uređenja koja izvorno nisu imala vezu s rimskim pravom u tom pogledu, predmet je analize koja slijedi.

\section{RAZVOJ VEZAN ZA FRANCUSKO PRAVO I SRODNA UREĐENJA}

Za potpunije razumijevanje razvoja neopravdanog obogaćenja u francuskom pravu i srodnim uređenjima potrebno je ukratko prikazati razvoj vezan za značenje pojma causa i njegovu relevantnost u prijenosu vlasništva. Općenito govoreći, taj pojam je imao različita značenja u rimskom pravu. ${ }^{42} \mathrm{U}$ kontekstu ove analize bitna su dva, i to causa kao pravni temelj i causa kao

36 Cf. Ibid., str. 882.

37 Cf. Zimmerman, op. cit. u bilj. 2, str. 835. sqq.

38 Vidjeti Hallebeek, op. cit. u bilj. 12 (1999), str. 66; cf. Feenstra, op. cit. u bilj. 24 (1972), str. 300.

39 Vidjeti za condictio ob turpem causam Leyser, A., Meditationes ad Pandectas 3-4, Leipzig, 1776., str. 71 sqq. (Spec. CXLVII), za condictio indebiti ibid., str. 80. sqq. (Spec. CXLVIII), za condictio furtiva ibid., str. 94. sqq. (Spec. CXLIX), te za condictio triticaria ibid., str. 103. sqq. (Spec. CL).

Vidjeti Leyser, A., Meditationes ad Pandectas 2, Leipzig, 1774., str. 635. sq.

Cf. Kupisch, B., Ungerechtfertigte Bereicherung, Heidelberg, 1987., str. 28. sqq.

42 Berger lakonski kaže kako je taj termin one of the vaguest terms of the Roman juristic language (vidjeti Berger, A., Encyclopedic Dictionary of Roman Law, Transactions of the American Philosophical Society, New Series 43, 2 (1953.), str. 333. sqq., str. 382.). Za više vidjeti citiranu literaturu u op.cit. 
cilj ili motiv kojemu određeni pravni posao teži. Osim u rimskim izvorima, navedena značenja prisutna su i u aristotelovskoj terminologiji, gdje bi se causa kao pravni temelj obveze mogla nazvati causa efficiens, a causa kao cilj ili motiv causa finalis. ${ }^{43}$ Terminološka diferencijacija ovog pojma u rimskim izvorima ostavila je traga i na recepciji rimskog prava, u kojoj je došlo do daljnjeg razvijanja njegova značenja. ${ }^{44}$ Kod glosatora i postglosatora termin causa je tako mogao označavati formu ili motiv dogovora. ${ }^{45}$ Causa se u djelu Baldusa de Ubaldisa (1327.--1400.), istaknutog komentatora, shvaćala kao svaka causa extrinsica, a zatim i kao causa impulsiva. ${ }^{46}$ Ako bi causa izostala, primjerice tako da određeni pactum ne bi imao formu (vestimentum) ili ako bi postojala causa falsa seu erronea, pravni posao ne bi imao pravnog učinka. ${ }^{47}$ Time je stvorena takozvana causa contractus, koju su preuzeli autori francuske, talijanske i španjolske doktrine ius commune. ${ }^{48} \mathrm{Na}$ tom temelju su Jean Domat (1625.-1696.) i Robert Joseph Pothier (1699.-1772.) izgradili doktrinu prema kojoj je causa contractus jedna od pretpostavki valjanosti ugovora. ${ }^{49}$ To pravilo je našlo svoj konkretni izraz i u francuskom građanskom zakoniku (Code civil des Français, dalje u tekstu CCF) ${ }^{50}$ iz $1804 .{ }^{51} \mathrm{Na}$ taj način u francusko pozitivno pravo ušao je specifični koncept takozvane kauze obveze..$^{52}$ Odgovarajući razvoj dogodio se i u talijanskom pravu, koje i u suvremenom uređenju poznaje koncept kauze obveze. ${ }^{53} \mathrm{Uz}$ navedeno, još je u francuskom Ancien Droit bilo prihvaćeno konsenzualno načelo glede tradicije, prema kojem je samim sporazumom stranaka dolazilo do prijelaza vlasništva. Isti razvoj dogodio se u praksi talijanskog javnog bilježništva 17. i 18. stoljeća. ${ }^{54} \mathrm{U}$ tom smislu kod tradicije nije se zahtijevalo da postoji titulus i modus, već je sam titulus dovodio do prijelaza vlasništva.

43 Za rimske izvore vidjeti primjerice D. 41, 2, 3, 21 (Paul. 54 ad ed.) (causa kao temelj stjecanja posjeda i vlasništva) i D. 39, 5, 2, 7 (Iul. 60 Dig.) (causa kao cilj određenog darovanja). Za Aristotela vidjeti METAPHYS. V, 1013a te opširnije o tomu u Falcon, A., Aristotle on Causality, The Stanford Encyclopedia of Philosophy (proljeće 2015), Zalta, E. N. (ur.). Dostupno na: https://plato. stanford.edu/archives/spr2015/entries/aristotle-causality.

Za više o pojmu causa u srednjovjekovnoj civilistici vidjeti Cortese, E., Causa del negozio giuridico (diritto intermedio), u: Moratti, C.; Pugliatti, S. (ur.), Enciclopedia del diritto 6, Milano, 1969., str. 535. sqq. i Fercia, R., "Quia vendidit, dare promisit", Cagliari, 2009., str. 11. sqq., a u kanonskom pravu Fedele, P., Causa del negozio giuridico (diritto canonico), u: Moratti, C.; Pugliatti, S. (ur.), Enciclopedia del diritto 6, Milano, 1969., str. 577. sqq.

45 Vidjeti Ranieri, F., Europäisches Obligationenrecht, Beč, 2009., str. 1048.

46 Drugim riječima, causa u smislu misaonog, razumskog motiva, koji je mogao biti i izvan pravnog posla. Cf. Ranieri, op. cit. u bilj. 45, str. 1049.

47 Ibid.

48 Ibid.

49 Vidjeti Kapor, V., Condictiones sine causa $i$ actio de in rem verso i moderno pravo, Zbornik Pravnog fakulteta u Zagrebu 1 (1969.), str. 5. sqq., str. 11.; Ranieri, op. cit. u bilj. 45, str. 1049.; te Fercia, op. cit. u bilj. 44, str. 99. sqq., s uputama na daljnju literaturu.

50 Korišten je tekst zakonika s izmjenama i dopunama na dan 1. listopada 2018. (Journal officiel de la République française).

51 Navedena odredba se nalazi u art. 1108 CCF-a. Ostale pretpostavke za valjanost ugovora jesu suglasnost strane koja se obvezuje, sposobnost ugovaratelja i određeni objekt kao sadržaj obvezivanja.

52 Za analizu kauze obveze s usporedbama srodnih instituta u komparativnom pravu vidjeti Nikšić, S., Kauza obveze i srodni instituti u poredbenom pravu, Zbornik Pravnog fakulteta u Zagrebu 56, 4 (2006), str. 1057. sqq., s uputama na daljnju literaturu.

53 Tako talijanski Codice civile (Codice civile italiano iz 1942., s izmjenama i dopunama na dan 11. siječnja 2018., Gazzetta Ufficiale della Repubblica Italiana. Dalje u tekstu: CCI) u art. 1325. za valjanost ugovora zahtijeva suglasnost stranaka, kauzu, objekt i formu (l'accordo delle parti, la causa, l'oggetto, la forma, quando risulta che è prescritta da legge sotto pena da nullità). Za više o kauzi u talijanskom pravu vidjeti Betti, E., Causa del negozio giuridico, u: Azara, A.; Eula, E. (ur.), Novissimo Digesto Italiano 3, Torino, 1959., str. 32. sqq.; Giorgianni, M., Causa del negozio giuridico (diritto romano), u: Moratti, C.; Pugliatti, S. (ur.), Enciclopedia del diritto 6, Milano, 1969., str. 547. sqq.; Cantillo, M., Le fonti delle obbligazioni, u: Lipari, N. et al. (ur.), Diritto civile 3/1, Milano, 2009., str. 2. sqq. 
U ovim pravnim okolnostima nije bilo previše mjesta za rimski kondikcijski sustav. Naime, on u velikoj mjeri počiva na shvaćanju kauze kao temelja nekog imovinskog prijelaza, što posebno vrijedi u odnosu na condictio sine causa u Justinijanovoj kodifikaciji, kao i u kontekstu naknadnog razvoja tog instituta. ${ }^{55}$ Koncept kauze obveze kao integralne pretpostavke valjanosti pravnog posla kakav postoji u francuskom pravu i povezanim poretcima u određenoj mjeri odstupa od navedenih rimskih shvaćanja. Uz to, navedeno konsenzualno načelo kod tradicije za sobom povlači posljedice vezane za sustavnu prednost vlasničke tužbe (vindikacije) u odnosu na kondikcijske zahtjeve. Naime, ako je u sustavu s konsenzualnim načelom titulus nevaljan, onda i ne dolazi do prijelaza vlasništva te je vlasniku i dalje dostupna vindikacija i načelno nema snažnije potrebe za alternativnim sredstvom poput kondikcije. Zbog svega navedenog od kondikcija je svoje mjesto u CCF-u mjesto našla jedino condictio indebiti, odnosno le paiement de l'indu u art. 1302 CCF-a. ${ }^{56}$ Odgovarajuća situacija postoji i u talijanskom pravu, gdje isti institut postoji pod nazivom ripetizione dell'indebito u art. 2033-2040 CCI-ja.

Što se tiče actio de in rem verso, ta tužba izvorno nije bila pustila snažnije korijenje u francuskom Ancien Droit. Antonius Faber (1557.-1624.) uopće nije prihvatio actio de in rem verso utilis, a Jacobus Cuiacius (1522.-1590.) za odgovarajuće trostrane odnose predlagao je actio negotiorum gestorum contraria utilis. ${ }^{57}$ Pothier također nije prihvatio actio de in rem verso te uz poznatu Pomponijevu sentencu D. 50, 17, 206 (Pomp. 9 ex var. lect.) vezuje condictio ex lege, odnosno actio in factum..$^{58}$ Stoga actio de in rem verso nije bila našla svoje mjesto u francuskom građanskom zakoniku. ${ }^{59}$

Međutim, ta je tužba ipak našla svoj put do francuskog prava. Na njezin razvoj utjecao njemački pravnik Karl Salomo Zachariä von Ligenthal (1769.-1843.) u svojem kapitalnom djelu Handbuch des französischen Zivilrechts (1808.-1827.). ${ }^{60}$ Von Ligenthal je konceptualno ujedinio različite odredbe iz CCF-a koje je smatrao primjenom tužbe actio de in rem verso, kako je bila koncipirana u ius commune, te ih podvrgnuo citiranom Pomponijevu načelu. ${ }^{61}$ Navedeni koncept je zatim bio prihvaćen i u teoriji i u sudskoj praksi. ${ }^{62}$ Vrhuncem navedenog razvoja može se smatrati poznati arrét Boudier iz $1892 .{ }^{63} \mathrm{U}$ tom slučaju, zakupoprimac nekog poljoprivrednog zemljišta kupio je gnojivo koje je iskoristio na zakupljenom zemljištu. Međutim, nije platio kupoprodajnu cijenu prodavatelju gnojiva. Zakupoprimac je naknadno postao in-

55 Detaljno, s uputama na daljnju literaturu, Zimmerman, op. cit. u bilj. 2, str. 854. sq., 856. sq. i 871. sqq.

56 U prijevodu: Povrat neduga.

57 Vidjeti Chiusi, T., Die actio de in rem verso im römischen Recht, München, 2001., str. 194.

58 Ibid.

59 U francuskom pravu neopravdanog obogaćenja smatralo se kako svi relevantni zahtjevi mogu biti pokriveni s condictio indebiti te primjenom instituta negotiorum gestio (tako Meier, S., Unjustified Enrichment, u: Basedow, J. et al. (ur.), The Max Planck Encyclopedia of European Private Law 2, Oxford, 2012., str. 1742. sqq., str. 1743.). Više o vezi negotiorum gestio s konceptom neopravdanog obogaćenja u francuskom pravu u Grauer, F., Die ungerechtfertigte Bereicherung im französischen Privatrecht, Heidelberg, 1930., str. 11. sqq.

60 Vidjeti Zachariä, K. S., Handbuch des Französischen Civilirechts 1-3, Heidelberg, 1808.-1827.

61 Cf. Kupisch, op. cit. u bilj. 41, str. 42

62 Vidjeti Grauer, op. cit. u bilj. 59, str. 31. sqq.; Kupisch, op. cit. u bilj. 41, str. 43.; Chiusi, op. cit. u bilj. 57, str. 194. sqq.

63 Vidjeti Grauer, op. cit. u bilj. 59, str. 35. sq.; Gomes, J., Unjust Enrichment: a Few Comparative Remarks, European Review of Private Law 9, 2 i 3 (2001), str. 449. sqq., str. 461.; Schlechtriem, P.; Coen, C.; Hornung, R., Restitution and Unjust Enrichment in Europe, European Review of Private Law 9, 2 i 3 (2001.), str. 377. sqq., str. 411.; Gallo, P., Unjust Enrichment: A Comparative Analysis, The American Journal of Comparative Law 40, 2 (1992), str. 431. sqq., str. 440., 456. Za praksu nakon arrét Boudier vidjeti Grauer, op. cit. u bilj. 59, str. 36. sqq. 
solventan, pa je prodavatelj gnojiva tražio isplatu od vlasnika zemljišta. Sudovi su odlučili da je vlasnik zemlje dužan platiti prodavatelju gnojiva i pritom su sugerirali da postoji opća tužba iz neopravdanog obogaćenja, koja obuhvaća i neizravno obogaćenje. ${ }^{64}$ Time su oblikovane pretpostavke za suvremenu actio de in rem verso kao opću tužbu za neopravdano obogaćenje. ${ }^{65}$ Naposljetku, u najnovijim izmjenama u CCF je 2016. godine uveden institut enrichissement injustifié (art. 1303 CCF), temeljen na navedenom razvoju u teoriji i sudskoj praksi, dok se u talijanskom uređenju isto dogodilo još i prije. ${ }^{66}$

\section{RAZVOJ VEZAN ZA NJEMAČKO PRAVO I SRODNA UREĐENJA}

Kako je već napomenuto, usus modernus pandectarum je uz kondikcijske zahtjeve u ovom području poznavao široku upotrebu actio de in rem verso utilis. ${ }^{67}$ To se očitovalo i u kodificiranju te tužbe u prve građanske zakonike koji su proizašli iz tog sustava, dakle Allgemeines Landrecht für die Preußischen Staaten iz 1794. i Allgemeines Bürgerliches Gesetzbuch iz 1811. ${ }^{68}$ Međutim, u njemačkoj praksi prije donošenja građanskog zakonika došlo je do izuzetno negativnog poimanja actio de in rem verso. Problematičnim se smatrala mogućnost neizravnog obogaćenja koja je prisutna kod te tužbe. Riječ je o mogućnosti da osiromašena osoba može tužiti obogaćenu, čak i kad ona nije odgovorna za povećanje imovine, nego je ono nastalo uz pomoć neke treće osobe, što je moguće ugrožavalo pravnu sigurnost. ${ }^{69}$ Stoga u pripremama za njemački građanski zakonik actio de in rem verso nije figurirala kao relevantna tužba vezana za neopravdano obogaćenje (ungerechtfertigte Bereicherung). ${ }^{70}$

64 Vidjeti Gallo, op. cit. u bilj. 63, str. 456. Više o obogaćenju u neopravdanom obogaćenju u Miladin, P.; Markovinović, H., Obogaćenje kao pretpostavka neopravdanog obogaćenja (stjecanja bez osnove), Zbornik Pravnog fakulteta u Zagrebu 68, 1 (2018), str. 5. sqq.

65 U literaturi se kao pretpostavke navode: obogaćenje jedne strane, osiromašenje druge, njihova uzročna veza, izostanak pravnog temelja te supsidijarnost tužbe (vidjeti u starijoj literaturi Grauer, op. cit. u bilj. 59, str. 47. sqq., te novije Chiusi, op. cit. u bilj. 57, str. 196. sq.).

66 Detaljnije o izmjenama u francuskom pravu u Descheemaeker, E., El nuevo derecho francés del enriquecimiento injustificado, u: Olmo García, P. del et al. (ur.), Enriquecimiento injustificado en la encrucijada: Historia, derecho comparado y propuestas de modernización, Navarra, 2017., str. 119. sqq. Za talijansko pravo vidjeti art. 2041 CCI. Cf. Giglio, F., La actio de in rem verso nel sistema del codice civile, Rivista di diritto civile 46, 2 (2000.), str. 249. sqq.; Schlesinger, P., Arricchimento, Azione di (diritto civile), u: Azara, A.; Eula, E. (ur.), Novissimo Digesto Italiano 1/2, Torino, 1958., str. 1004. sqq.; Sirena, P., L'azione generale di arricchimento senza causa, u: Lipari, N. et al. (ur.), Diritto civile 3/1, Milano, 2009., str. 554. sqq.

67 Vidjeti Feenstra, op. cit. u bilj. 24 (1972), str. 299. sq.; Hallebeek, op. cit. u bilj. 12 (2002), str. 93. Za analizu razvoja specifične condictio ob turpem causam u tom kontekstu vidjeti Hagen, O., Die condictio ob turpem causam im gemeinen Rechte und Bürgerlichen Gesetzbuche, Leipzig, 1913.

68 O tomu više u Kupisch, B., Ungerechtfertigte Bereicherung. Usus modernus pandectarum in Deutschland unter Berücksichtigung des preußischen Allgemeinen Landrechts (ALR) und des österreichischen Allgemeinen bürgerlichen Gesetzbuchs (ABGB), u: Schrage, E. (ur.), Unjust Enrichment, Berlin, 1999., str. 237. sqq., posebno str. 249. sqq. Za detalje o actio de in rem verso u Allgemeines Landrecht für die Preußischen Staaten iz 1794. vidjeti Kupisch, B., Die Versionsklage, Heidelberg, 1965., str. 57. sqq. Za više o važnosti usus modernus pandectarum općenito za Allgemeines Bürgerliches Gesetzbuch, odnosno OGZ, vidjeti Wesener, G., Zur Bedeutung des Usus modernus pandectarum für das österreichische $A B G B$, u: Harrer, F. et al. (ur.), Gedächtnisschrift für Theo Mayer-Maly, Beč, 2011., str. 571. sqq. Za više općenito o neopravdanom obogaćenju u njemačkom srednjovjekovnom pravu vidjeti Schartl, R., Ungerechtfertigte Bereicherung nach deutschen Rechtsquellen des Mittelalters, Tijdschrift voor Rechtsgeschiedenis 60 (1992), str. 109. sqq.

Vidjeti Gomes, op. cit. u bilj. 63, str. 459.

Iz prethodnog izlaganja može se vidjeti kako je sudska praksa u Francuskoj odigrala ključnu ulogu u prihvaćanju te tužbe u pravni sustav, dok su u Njemačkoj upravo praktični problemi uvjetovali izostavljanje te tužbe iz koncepta neopravdanog obogaćenja. S druge strane, i francuska i njemačka teorija, kako se može vidjeti u tekstu, bile su složne u pogledu neprihvatljivosti actio de in 
Uz to, određena shvaćanja vezana za opće privatnopravno uređenje proizašla iz pandektistike uzrokovala su sustavnu superiornost kondikcijskih zahtjeva kao temeljnih tužbi iz neopravdanog obogaćenja. Riječ je o sljedećem. Već je u prethodnom dijelu istaknuta relevantnost načina stjecanja vlasništva u kontekstu koji je predmet analize. Tako prema spomenutom konsenzualnom načelu samim sporazumom dolazi do prijelaza vlasništva te su na određeni način ujedinjeni titulus i modus, odnosno pravni temelj i način stjecanja vlasništva. Za razliku od toga, u njemačkom i srodnim pravnim sustavima postojalo je načelo odvojenosti pravnog temelja i načina stjecanja. ${ }^{71}$

Uz to, Friedrich Karl von Savigny (1779.-1861.) razvio je posebnu doktrinu prema kojoj je prijenos posjeda kao modus apstraktni stvarnopravni posao. Time je uspostavljen takozvani Abstraktionsprinzip, prema kojem valjanim načinom stjecanja (modus) može doći do prijelaza vlasništva čak i ako je temelj stjecanja (titulus) nevaljan. ${ }^{72}$ Posljedica navedenog pravila jest da će otuđivatelj izgubiti vlasništvo ako se izvrši valjani modus, čak i ako je titulus, primjerice kupoprodajni ugovor, nevaljan. Gubitkom vlasništva izgubit će se i pravo na reivindikaciju te se javlja ozbiljan problem nedostatka pravne zaštite. Kao način ostvarenja te pravne zaštite, u skladu sa svojom izvornom i tradicionalnom ulogom, javljaju se upravo rimske kondikcije.

Zbog svega navedenog u Savignyjevoj koncepciji postoji jedinstvena opća tužba, condictio sine causa generalis, koja obuhvaća bitne slučajeve primjene vezane za rimske kondikcije. ${ }^{73}$ Taj koncept je prihvaćen i u pripremama za donošenje njemačkog građanskog zakonika (Bürgerliches Gesetzbuch, dalje u tekstu BGB $)^{74}$ iz $1900 .{ }^{75}$ Ovdje valja primijetiti kako su prvi nacrti švicarskog i njemačkog uređenja predviđali niz različitih kondikcija preuzetih iz ius commune, na čijem kraju se nalazila condictio sine causa kao kategorija koja obuhvaća sve ostale neimenovane slučajeve. ${ }^{76}$ Taj sustav je strukturalno i konceptualno sličan Justinijanovu, gdje je nakon enumeracije pojedinih kondikcija bila navedena condictio sine causa kao rezidualna kategorija za preostale neimenovane slučajeve. ${ }^{77}$ Međutim, u pripremama za donošenje njemačkog građanskog zakonika nakon snažnih kritika ipak je bio prihvaćen sustav koji na početku sadrži jedan opći kondikcijski zahtjev te zatim niz primjera. ${ }^{78}$ Navedeno uređenje i danas je na snazi, u par. 812.-822. BGB-a.

rem verso te isticanja kondikcije kao osnovne tužbe iz neopravdanog obogaćenja. Može se reći da to ide u prilog konceptualnoj i praktičnoj optimalnosti kondikcije kao tužbe iz neopravdanog obogaćenja.

71 Vidjeti Ranieri, op. cit. u bilj. 45, str. 1055. sq.

72 Vidjeti ibid., te Fercia, op. cit. u bilj. 44, str. 70. sqq., s uputama na daljnju literaturu.

73 Vidjeti Hallebeek, op. cit. u bilj. 12 (2002), str. 93. Za analizu kondikcija vidjeti Savigny, F. von, System des heutigen römischen Rechts 5, Berlin, 1841., str. 503. sqq.

74 Korišten je tekst zakonika s izmjenama i dopunama na dan 31. siječnja 2019. (Bundesgesetzblatt).

75 Za više vidjeti Mugdan, B., Die gesammten Materialien zum Bürgerlichen Gesetzbuch für das Deutsche Reich 2, Berlin, $1899 .$, str. 464. sqq. i 1169. sqq.

76 Vidjeti Kapor, op. cit. u bilj. 49, str. 14. Takvo je uređenje postojalo i u Općem imovinskom zakoniku Kneževine Crne Gore Balda Bogišića, (cf. Miladin, P., Običaji, kondikcije, ortaštvo i ugovorna kazna prema Bogišićevu Općem imovinskom zakoniku za Crnu Goru (OIZ) i hrvatskom Zakonu o obveznim odnosima (ZOO), u: Kregar, J. et al. (ur.), Bogišić i kultura sjećanja, Zagreb, 2008.-2011., str. 66. sqq., str. 83.).

78 Predmet kritike je bila condictio sine causa specialis kao zasebna kategorija koja bi mogla konkurirati s bilo kojim drugim kondikcijskim zahtjevom. Za razliku od toga, kod naknadno prihvaćenog sustava s jednom općom tužbom iz neopravdanog obogaćenja, pojedini navedeni slučajevi koji slijede nakon opće tužbe samo su primjeri načina njezine primjene. Cf. Zimmerman, op. cit. u bilj. 2, str. 871 . sqq. 
Navedeni opći zahtjev može se smatrati jednim oblikom konkretizacije već navedenih Pomponijevih sentenci kojima se zabranjuje neopravdano obogaćenje na teret druge osobe. Pod neopravdanim obogaćenjem u ovom slučaju obuhvaćeni su ne samo zahtjevi koji su se tradicionalno utuživali kondikcijama, već i neki drugi. Tu se podrazumijevaju oni koji su se u rimskom pravu utuživali određenim pretorskim tužbama, ${ }^{79}$ ili neki od onih koji su se u ius commune utuživali preko actio de in rem verso..$^{80}$ Time je stvoren opći koncept kondikcijske zaštite, tipičan za njemački i srodne pravne poretke, koji je konceptualno i terminološki postao istovjetan s konceptom neopravdanog obogaćenja.

\section{ENGLESKI COMMON LAW I UGARSKO PRIVATNO PRAVO}

Englesko pravo je konceptualno izdvojeno od kontinentalnih europskih pravnih sustava te je u njemu načelno manje prisutan utjecaj rimskog prava, što naravno vrijedi i u pogledu neopravdanog obogaćenja. ${ }^{81}$ Slično tomu, ugarsko privatno pravo u razvojnom rasponu od važenja u dijelovima Habsburške Monarhije do primjene u Kraljevini SHS odnosno Kraljevini Jugoslaviji u istom kontekstu također nije poznavalo snažniji utjecaj rimskog prava, kako će se vidjeti iz teksta koji slijedi. Ipak, oba navedena sustava u jednom su trenutku svojeg razvoja usvojili određene elemente rimskog pravnog uređenja.

Što se tiče engleskog common law sustava, unjust ili unjustified enrichment ${ }^{82}$ u razvijenom konceptu smatra se vezanim za šire područje prava nazvano law of restitution. ${ }^{83}$ Povijesno su se u navedenom području koristila različita pravna sredstva čija je primjena ovisila o konkretnim okolnostima. Tako se još u engleskom srednjovjekovlju kao jedno od prvih sredstava u ovom kontekstu može smatrati kvazikontraktna tužba assumpsit, koju je jedna strana koristila protiv druge kad ona ne bi izvršila svoju obvezu. Iz nje su bile proizašle kvazikontraktne tužbe

79 Vidjeti Coing, op. cit. u bilj. 31, str. 399.

$80 \quad$ Vidjeti Kupisch, op. cit. u bilj. 41, str. 41.

81 Za više o utjecaju rimskog prava u Engleskoj općenito vidjeti Winkler, J. F., Roman Law in Anglo-Saxon England, The Journal of Legal History 13, 2 (1992), str. 101. sqq.; Korporowicz, Ł. J., Roman Law in Roman Britain: An Introductory Survey, The Journal of Legal History 33, 2 (2012), str. 133. sqq. Za preglednu analizu rimskog prava i engleskog common law sustava vidjeti Buckland, W.; McNair, A., Roman Law and Common Law, Cambridge, 1974.

$82 \mathrm{U}$ engleskoj teoriji općenito se razlikuje pristup koji uzima u obzir juristic reasons i onaj koji se temelji na unjust factors. Kontinentalni sustavi prema tome uzimaju u obzir juristic reasons i odobravaju povrat stečenog ako ne postoji pravna osnova na strani stjecatelja. Engleski sustav, s druge strane, počiva na pristupu koji uvažava unjust factors koji postoje ili ne postoje na strani prenositelja te se u skladu s tim odobrava povrat. U praksi i literaturi razvila se posebna teorija koja objašnjava značenje riječi unjust u ovoj sintagmi (o tomu vidjeti Edelman, J., The Meaning of "Unjust" in the English Law of Unjust Enrichment, European Review of Private Law 14, 3 (2006), str. 309. sqq.; Hedley, S., "Unjust" at Common Law: So Many Concepts, So Little Clarity, European Review of Private Law 14, 3 (2006), str. 399. sqq.; Meier, S., Unjust factors and legal grounds, u: Johnston, D.; Zimmerman, R. (ur.), Unjustified Enrichment, Cambridge, 2004., str. 37. sqq.; Krebs, T., In defence of unjust factors, u: Johnston, D.; Zimmerman, R. (ur.), Unjustified Enrichment, Cambridge, 2004., str. 76. sqq.; Zimmerman, R., Unjustified Enrichment: The Modern Civilian Approach, Oxford Journal of Legal Studies 15, 3 (1995), str. 403. sqq., str. 415. sq.). Za raspravu vezanu za termine unjust i unjustified enrichment vidjeti Giglio, F., A Systematic Approach to "Unjust" and "Unjustified" Enrichment, Oxford Journal of Legal Studies 23, 3 (2003), str. 455. sqq.

83 Vidjeti Kupisch, op. cit. u bilj. 41, str. 45. sqq.; Schrage, E.; Barry, N., Unjust Enrichment and the Law of Restitution: A Comparison, u: Schrage, E., (ur.), Unjust Enrichment, Berlin, 1999., str. 9. sqq.; Birks, P., An Introduction to the Law of Restitution, Oxford, 1985. str. 16. sqq. 
money had and received, money paid ili money laid out, quantum meruit i quantum valebat. ${ }^{84} \mathrm{Uz}$ to je na temelju sudske prakse bilo razvijeno i sredstvo pod nazivom waiver of tort, prema kojem bi se tužitelj mogao odreći naknade štete i tražiti samo ono što je protupravno bilo oduzeto iz njegove imovine. ${ }^{85}$

Međutim, na ovaj autentični common law sustav u naknadnom razvoju u određenoj mjeri počeli su utjecati izvorno rimski koncepti. Tako se još u 18. st. u sudskoj praksi počelo naglašavati načelo zabrane neopravdanog obogaćenja na teret drugih, pri čemu su se pojedini suci pozivali na pravičnost, prirodno pravo i slično, sintagme podudarne s citiranim Pomponijevim sentencama korištenima u kontekstu kondikcijske zaštite i stvaranja koncepta neopravdanog obogaćenja u srednjovjekovnoj civilistici. Pritom se navedeni način nastanka obveze izričito imenovao kao quasi-contract, čime je priznat kontinentalni civilistički utjecaj na common law. Isto se nastavilo i u praksi engleskih sudova u 20. st. ${ }^{86}$ Usporedno s tim, u engleskoj teoriji tijekom 20. st. pojavili su se prijedlozi za usvajanje neopravdanog obogaćenja kao općeg i samostalnog izvora obveze. ${ }^{87}$ Prema navedenim tezama, kao osnovni kriteriji za ostvarivanje tog zahtjeva navodili su se obogaćenje na jednoj strani i osiromašenje na drugoj te nepravednost zadržanja. ${ }^{88} \mathrm{U}$ tom smislu i u teoriji je vidljiv utjecaj koncepata temeljenih na rimskim pravnim načelima te rimskom kondikcijskom sustavu, posebno u obliku kakav je postojao u pandektistici i u BGB-u. ${ }^{89}$ Tako je englesko pravo u svojem naknadnom razvoju prava neopravdanog obogaćenja došlo pod (posredni) utjecaj rimskog prava unatoč izvornoj nepovezanosti s njim.

Sličan razvoj može se primijetiti vezano za ugarsko privatno pravo, to jest pravo Tripartita u njegovu važenju u Habsburškoj Monarhiji te nastavak njegove primjene u Kraljevini SHS, odnosno Kraljevini Jugoslaviji. Riječ je o pravu čiju je okosnicu, uz druge izvore, činio Tripartit

84 U ovom se smislu assumpsit koristi tek od poznatog slučaja Slade's Case iz 1602. Za više vidjeti Palmer, G., Historyof Restitution in Anglo-American Law, u: Caemmerer, E. von; Schlechtriem, P. (ur.), International Encyclopedia of Comparative Law 10, Tübingen, 2007., poglavlje 3, str. 3 sqq., str. 9. sqq.; Schäfer, F., Das Bereicherungsrecht in Europa, Berlin, 2001., str. 500. sqq.; Ibbetson, D., Unjust Enrichment in English Law, u: Schrage, E., (ur.), Unjust Enrichment and the Law of Contract, London, 2001., str. 33. sqq., str. 38. sqq.; Heemann, M., Action for money had and received, Berlin, 1996., str. 21. sq., 133. sqq.; Baker, J., The Use of Assumpsit for Restitutionary Money Claims 1600-1800, u: Schrage, E. (ur.), Unjust Enrichment, Berlin, 1999., str. 31. sqq.; Dawson, J., Unjust Enrichment, Boston, 1951., str. 10. sqq.; Martinek, M., Der Weg des Common Law zur allgemeinen Bereicherungsklage. Ein später Sieg des Pomponius?, Rabels Zeitschrift für ausländisches und internationales Privatrecht 47 (1983.), str. 284 sqq., str. 288 sq.; Gallo, op. cit. u bilj. 63, str. 432. sqq.; Dickson, B., The Law of Restitution in the Federal Republic of Germany: A Comparison with English Law, The International and Comparative Law Quarterly 36, 4 (1987), str. 751. sqq., str. 753. Za povijest engleskog neopravdanog obogaćenja prije 1600. vidjeti Ibbetson, D., Unjust Enrichment in England before 1600, u: Schrage, E. (ur.), Unjust Enrichment, Berlin, 1999., str. 121. sqq.

85 Palmer, op. cit. u bilj. 84, poglavlje 3, str. 10.; Schäfer, op. cit. u bilj. 84, str. 602. sq.; Heemann, op. cit. u bilj. 84, str. 173. sqq.; Martinek, op. cit. u bilj. 84, str. 289. sq.; Gallo, op. cit. u bilj. 63, str. 435. sq.

86 Vidjeti mišljenje lorda Mansfielda u slučaju Moses vs. Macferlan iz 1760., zatim lorda Wrighta u slučaju Fibrosa Spolka Akcyjna vs. Fairbairn Lawson Combe Barbour, Ltd. iz 1943. i lorda Denninga u slučaju Hussey vs. Palmer iz 1972. (vidjeti Palmer, op. cit. u bilj. 84, poglavlje 3, str. 11., 15.; Schäfer, op. cit. u bilj. 84, str. 500. sq., str. 505., bilj. 35; Heemann, op. cit. u bilj. 84, str. 23. sqq.; Birks, P.; McLeod, G., The Implied Contract Theory of Quasi-Contract: Civilian Opinion Current in the Century before Blackstone, Oxford Journal of Legal Studies 46, 6 (1986.), str. 46. sqq., str. 47., 78.). Za cjelokupni i temeljiti prikaz povijesti prava neopravdanog obogaćenja u engleskom pravu vidjeti posebno Heemann, op. cit. u bilj. 84.

87 Tako se primjerice Peter Birks zalaže za jedinstven i opći koncept neopravdanog obogaćenja (vidjeti Meier, op. cit. u bilj. 59, str. 1744.; Zimmerman, op. cit. u bilj. 2, str. 894.). U istom smislu kao i Birks vidjeti primjerice Ibbetson, op. cit. u bilj. 84 (2001), str. 52. i Danneman, G., Unjust Enrichment by Transfer: Some Comparative Remarks, Texas Law Review 79, 7 (2001), str. 1837. sqq., str. 1839. sq. No ima i suprotnih stavova, vidjeti tako Webb, C., What is Unjust Enrichment?, Oxford Journal of Legal Studies 29, 2 (2009), str. 215. sqq. i Hedley, S., Unjust Enrichment, Cambridge Law Journal 54, 3 (1995), str. 578. sqq.

89 Cf. Schäfer, op. cit. u bilj. 84, str. 683. sq. Op. cit. općenito sadrži komparativnu analizu njemačkog i engleskog prava neopravdanog obogaćenja. Uz to, vidjeti i Dickson, op. cit. u bilj. 84. 
Stjepana Werböczyja iz $1514 .^{90}$ Osim što je navedeni pravni sustav bio na snazi u dijelovima Habsburške Monarhije koji su uključivali i određene hrvatske krajeve, njegova primjena je bila moguća i u državama nastalim nakon raspada te Monarhije. ${ }^{91} \mathrm{U}$ svakom slučaju, privatno pravo Tripartita u izvornom obliku nije poznavalo rimski kondikcijski sustav u bilo kojem relevantnom smislu. Komentari tog prava u ovom kontekstu spominju jedino indebiti solutio, odnosno plaćanje neduga kao kvazikontrakt, ali u pravilu u kontekstu obrađivanja tematike realnih ugovora, odnosno zajma (mutuum) i problematike duga (debitum). Pritom kao tužbu navode actio indebiti soluti, a ne condictio. ${ }^{92}$ Međutim, u komentarima istog privatnopravnog sustava u Kraljevini SHS, odnosno Kraljevini Jugoslaviji ipak se koristi terminologija tipičnog kondikcijskog uređenja. ${ }^{93} \mathrm{U}$ tom smislu navodi se postojanje neopravdanog obogaćenja ${ }^{94}$ kao posebnog izvora obveza, temeljenog na načelu prema kojem Iure naturae aequum est, neminem cum alterius detrimento fieri locupletiorem, što je zapravo prije citirana Pomponijeva sentenca koja se dovodi u vezu s neopravdanim obogaćenjem i kondikcijskom zaštitom. ${ }^{95}$ Osim toga, izrijekom se nabrajaju slučajevi iz prakse koji se smatraju obuhvaćeni navedenim načelom te se definiraju kao pojedine kondikcije iz rimskog prava i to poimence condictio indebiti, condictio causa data causa non secuta ili u obliku kao condictio ob causam datam, causam non secutam, zatim condictio ob turpem vel iniustam causam, condictio sine causa i condictio ob causam finitam. ${ }^{96}$

Time se vidi kako je i u ovom primjeru rimski kondikcijski sustav, u pandektističkoj obradi koja je u to vrijeme već bila kodificirana u njemački BGB, utjecao na poimanje prava neopravdanog obogaćenja u uređenju izvorno bez snažnijeg utjecaja rimskog prava u analiziranom području. Ovaj razvoj bi se možda mogao objasniti utjecajem pandektistike te austrijskog prava i drugih prava koja su vrijedila u posebnim pravnim područjima tadašnje države. ${ }^{97}$ To vrijedi

90 Za latinski tekst Tripartita uz engleski prijevod vidjeti Bak, J. et al. (ur.), Decreta regni mediaevalis Hungariae 5: Tripartitum opus iuris consuetudinarii inclyti regni Hungariae per Stephanum de Werbewcz editum, Budimpešta 2005. Više o Tripartitu i Stjepanu Werböczyju vidjeti Péter, L., The Irrepressible Authority of the Tripartitum, u: op. cit., str. xiii. sqq. i Rady, M., Stephen Werböczy and his Tripartitum, u: op. cit., str. xxvii. sqq. Detaljnije o izvorima privatnog prava Tripartita u Lanović, M., Privatno pravo Tripartita, Zagreb, 1929., 10. sqq.

91 Detaljnije, s uputama na daljnju literaturu u Radovčić, V., Pokušaj kodifikacije građanskog prava u staroj Jugoslaviji ("Predosnova građanskog zakonika za kraljevinu Jugoslaviju"), Radovi Zavoda za hrvatsku povijest 7, 1 (1975), str. 249. sqq., str. 255. sq.; Petrak, M., Rimsko pravo kao pozitivno pravo u Republici Hrvatskoj. Prilog tumačenju Zakona o načinu primjene pravnih propisa donesenih prije 6. travnja 1941. godine, Hrvatska pravna revija 10 (2006), str. 1. sqq., str. 8. sq.

92 Vidjeti Huszty, S., Juriprudentia practica, lib. II, Eger, 1745., str. 35.; Fleischhacker, J., Institutiones juris hungarici 2, Bratislava, 1795., str. 369., 374. sqq.; Kövy, S., Elementa jurisprudentiae hungaricae, Košice, 1807., str. 358.; Kelemen, I., Institutiones juris privati hungarici 2/2, Pešta, 1814., str. 1147. sq.; Jung, J. von, Darstellung des ungarischen Rechts, Beč, 1827., str. 37. sq. Od navedenih referenci jedino Fleischhacker tretira indebiti solutio izravno u poglavlju o kvazikontraktima.

93 Analizirani komentari odnose se na privatno pravo u Vojvodini, ali su analogno sasvim primjenjivi općenito na ugarsko privatno pravo koje se primjenjivalo u Kraljevini SHS, odnosno Kraljevini Jugoslaviji, pa i na Međimurje i Baranju kao hrvatske krajeve, jer je riječ o istom pravnom području (vidjeti Radovčić, op. cit. u bilj. 91, str. 255. sq.).

94 Koriste se termini nepravedno obogaćenje (Piškulić, Z.; Džerdž, I., Osnovi privatnoga prava u Vojvodini, Beograd, 1924., str. 217.), neosnovano obogaćenje (Bogdanfi, G.; Nikolić, N., Opšte privatno pravo koje važi u Vojvodini, Pančevo, 1925., peta glava, str. 174.) i obogaćenje u nedostatku pravne osnove (Jesensky, A.; Protić, P., Privatno pravo u Vojvodini, Sombor, 1922., str. 328.).

D. 50, 17, 206 (Pomp. 9 ex var. lect.). Izričito pozivanje na latinsku sentencu postoji u Jesensky i Protić, op. cit. u bilj. 94, str. 328., dok se u Piškulić i Džerdž, op. cit. u bilj. 94, str. 217. i Bogdanfi i Nikolić, op. cit. u bilj. 94, str. 174. nalazi prijevod sentence kao opće pravno načelo. Slična sintagma može se ipak naći i u prijašnjem komentaru privatnog prava Tripartita, ali isključivo vezano za tužbu kojom se vraća indebitum solutum (Huszty, op. cit. u bilj. 92, str. 35.: neminem liceat locupletari cum damno alterius). 
posebno uzevši u obzir činjenicu da je ugarsko privatno pravo imalo više različitih izvora te da je kao načelno nekodificirano pravo bilo podložno i prilagodljivo različitim utjecajima i izmjenama. ${ }^{98}$ Međutim, smatramo da je prihvaćanju kondikcijskog sustava u pandektističkoj koncepciji, temeljenom na justinijanovskom uređenju, njegova teoretska razrađenost i dokazanost u praksi u najmanju ruku barem dijelom pomogla.

\section{ZAKLJUČAK}

Koncept neopravdanog obogaćenja kao općeg i samostalnog izvora obveze nedvojbeno nije postojao u rimskom pravu. Kako se može vidjeti iz obavljene analize, riječ je o rezultatu srednjovjekovne obrade rimskih izvora. U tom procesu određenu ulogu odigrala je teologija, odnosno kanonistička doktrina. Međutim, ključni su u svakom slučaju bili rimski izvori, i to u dvostrukom smislu. Najprije, iz njih se ekstrapoliralo temeljno načelo prema kojemu je za pravni poredak neprihvatljivo stjecanje ili bogaćenje jedne osobe na teret druge. Osim toga, iz rimskoga prava preuzete su pojedine tužbe koje su se koristile u uspostavi i formulaciji neopravdanog obogaćenja kao općeg i samostalnog izvora obveze. Tu je na prvom mjestu riječ o kondikciji (condictio), odnosno različitim kondikcijskim zahtjevima Justinijanova prava (condictiones), koji su bili najvažnije sredstvo u analiziranom razvoju. Osim toga, s obzirom na izvornu primjenu iznenađujuće istaknuti položaj dobila je i actio de in rem verso, odnosno takozvani verzijski zahtjev. Uz to, za sankciju neopravdanog obogaćenja povijesno je čak korištena i jedna varijanta actio negotiorum gestorum. U svjetlu rečenog, za razvoj neopravdanog obogaćenja kao općeg i samostalnog izvora obveza svakako najvažnija uloga pripada civilističkoj obradi rimskog prava, u srednjovjekovlju te u naknadnoj recepciji rimskog prava, gdje je posebno relevantan bio usus modernus pandectarum.

Srednjovjekovna obrada i različiti smjerovi recepcije stvorili su dvije različite temeljne razvojne tendencije na europskom kontinentu. Jedna je snažnije vezana za francusko pravo i CCF, a druga za njemačko pravo i BGB. U grubim crtama, može se reći kako njemačko i srodna uređenja snažnije slijede kondikcijski sustav te u zakonodavstvu poznaju različite kondikcije uz opću tužbu iz neopravdanog obogaćenja koje je koncipirano kao samostalni izvor obveze. Nasuprot tomu, zbog određenih unutrašnjih strukturalnih razlika, francusko i srodna uređenja ne poznaju široko razgranat kondikcijski sustav, a opća tužba iz neopravdanog obogaćenja kao samostalnog izvora obveza temelji se na verzijskom zahtjevu, što je izvorno actio de in rem verso rimskoga prava. Englesko pravo i common law u ovom pogledu izvorno nisu bili snažnije utemeljeni na rimskom pravu, što bi se moglo reći i za ugarsko privatno pravo, odnosno pravo Tripartita. Međutim, u naknadnom razvoju, posebno u sudskoj praksi i u teoriji, i u engleskom common law sustavu i u primjeni ugarskog privatnog prava u Kraljevini SHS, odnosno Kraljevini Jugoslaviji vidljiva je jasna konvergencija s kontinentalnim sustavima u skladu s rimskom pravnom tradicijom. Pritom se snažnija veza ostvaruje s kondikcijskim sustavima vezanim za BGB. Sve navedeno upućuje na zaključak kako je rimsko pravo u svakom slučaju temelj razvoja

J.; Svoboda, M., Privatno pravo u Vojvodini i Medimurju, Zagreb, 1926., posebno što se tiče kondikcija primjerice na str. 182. sq. (glede condictio indebiti iz par. 1431. i condictio ob causam finitam iz par. 1435.). 
neopravdanog obogaćenja kao općeg i samostalnog izvora obveza, a pritom je autentičniji i u razvoju prisutniji utjecaj rimskog kondikcijskog sustava, odnosno različitih condictiones Justinijanova prava.

\section{IZVORI}

BGB = Bürgerliches Gesetzbuch iz 1900., s izmjenama i dopunama na dan 31. siječnja 2019., Bundesgesetzblatt.

C. = Codex Iustinianus. Preuzeto iz: Krüger, P. (ur.), Corpus iuris civilis, volumen secundum: Codex Iustinianus, Berlin, 1892.

CCF = Code civil des Français iz 1804., s izmjenama i dopunama važećim na dan 1. listopada 2018., Journal officiel de la République française.

CCI = Codice civile italiano iz 1942., s izmjenama i dopunama važećim na dan 11. siječnja 2018., Gazzetta Ufficiale della Repubblica Italiana.

D. = Digesta seu Pandectae Iustiniani. Preuzeto iz: Mommsen, T.; Krueger, P.; Watson, A. (ur.), The Digest of Justinian, vol. I-IV, Philadelphia, 1998.

Decretum Gratiani = Decretum Gratiani seu Concordantia discordantium canonum. Preuzeto iz: Richter, E. L.; Friedberg, E. (ur.), Corpus iuris canonici, pars prior: Decretum magistri Gratiani, Leipzig, 1879.

EPIST = Sanctus Augustinus Hipponensis, Epistolae. Preuzeto iz: Migne, J. P., Sancti Aurelii Augustini hipponensis episcopi opera omnia, tomus secundus (Patrologiae cursus completus, series prima, tomus XXXIII), Paris, 1865.

EXOD = Exodus, Biblia Sacra Vulgata Sixto-Clementina. Preuzeto iz: Ess, L. van (ur.), Biblia Sacra, Vulgatae Editionis, Sixti V et Clementis VIII, 1590, 1592, 1593, 1598, Tübingen, 1822.-1824.

Liber Sextus = Liber Sextus, Bonifatius VIII. Preuzeto iz: Decretales D. Gregorii Papae, suae integritati una cum glossis restitutae, Romae, 1582. Dostupno na: http://digital.library.ucla. edu/ canonlaw/.

METAPHYS = Aristotel, Metaphysica, $\tau \dot{\alpha} \mu \varepsilon \tau \dot{\alpha} \tau \dot{\alpha} \varphi v \sigma \iota \kappa \dot{\alpha}$ (tà metà tà fysiká, odnosno Metafizika). Prijevod preuzet iz: Tredennick, H., Aristotle, Metaphysics, books I-IX, Cambridge, 1989.

SUMMA = Sanctus Thomas Aquinas, Summa Theologiae. Preuzeto iz: Alarcón, E. (ur.), Corpus Thomisticum, Pamplona, 2000.

\section{LITERATURA}

1. Bak, J. et al. (ur.), Decreta regni mediaevalis Hungariae 5: Tripartitum opus iuris consuetudinarii inclyti regni Hungariae per Stephanum de Werbewcz editum, Budimpešta, 2005.

2. Baker, J., The Use of Assumpsit for Restitutionary Money Claims 1600-1800, u: Schrage, E. (ur.), Unjust Enrichment, Berlin, 1999., str. 31. sqq.

3. Bar, C. von; Swann, S. (ur.), Unjustified Enrichment (PEL Unj.Enr.), München, 2010.

4. Berger, A., Encyclopedic Dictionary of Roman Law, Transactions of the American Philosophical Society, New Series 43, 2 (1953), str. 333. sqq.

5. Betti, E., Causa del negozio giuridico, u: Azara, A.; Eula, E. (ur.), Novissimo Digesto Italiano 3, Torino, 1959., str. 32. sqq. 
6. Birks, P., An Introduction to the Law of Restitution, Oxford, 1985.

7. Birks, P.; McLeod, G., The Implied Contract Theory of Quasi-Contract: Civilian Opinion Current in the Century before Blackstone, Oxford Journal of Legal Studies 46, 6 (1986), str. 46. sqq.

8. Bogdanfi, G.; Nikolić, N., Opšte privatno pravo koje važi u Vojvodini, Pančevo, 1925.

9. Boyle, L. E., Liber Sextus, u: Halfmann, J. (ur.), New Catholic Encyclopedia 8, Detroit, 2003., str. 536.

10. Buckland, W.; McNair, A., Roman Law and Common Law, Cambridge, 1974.

11. Cantillo, M., Le fonti delle obbligazioni, u: Lipari, N. et al. (ur.), Diritto civile 3/1, Milano, 2009., str. 2. sqq.

12. Chiusi, T., Die actio de in rem verso im römischen Recht, München, 2001.

13. Coing, H., Zum Einfluß der Philosophie des Aristoteles auf die Entwicklung des römischen Rechts, ZRGRA 69 (1952), str. 24. sqq.

14. Coing, H., Zur Lehre von der ungerechtfertigten Bereicherung bei Accursius, ZRG-RA 80 (1963), str. 396. sqq.

15. Cortese, E., Causa del negozio giuridico (diritto intermedio), u: Moratti, C.; Pugliatti, S. (ur.), Enciclopedia del diritto 6, Milano, 1969., str. 535. sqq.

16. Danneman, G., Unjust Enrichment by Transfer: Some Comparative Remarks, Texas Law Review 79, 7 (2001), str. 1837. sqq.

17. Dawson, J., Unjust Enrichment, Boston, 1951.

18. Descheemaeker, E., El nuevo derecho francés del enriquecimiento injustificado, u: Olmo García, P. del et al. (ur.), Enriquecimiento injustificado en la encrucijada: Historia, derecho comparado y propuestas de modernización, Navarra, 2017., str. 119. sqq.

19. Dickson, B., The Law of Restitution in the Federal Republic of Germany: A Comparison with English Law, The International and Comparative Law Quarterly 36, 4 (1987), str. 751. sqq.

20. Edelman, J., The Meaning of "Unjust" in the English Law of Unjust Enrichment, European Review of Private Law 14, 3 (2006), str. 309. sqq.

21. Falcon, A., Aristotle on Causality, The Stanford Encyclopedia of Philosophy (proljeće 2015), Zalta, E. N. (ur.). Dostupno na: https://plato.stanford.edu/archives/ spr2015/entries/aristotle-causality.

22. Fedele, P., Causa del negozio giuridico (diritto canonico), u: Moratti, C.; Pugliatti, S. (ur.), Enciclopedia del diritto 6, Milano, 1969., str. 577. sqq.

23. Feenstra, R., Die ungerechtfertigte Bereicherung in dogmengeschichtlicher Sicht, Ankara Üniversitesi Hukuk Facültesi Dergisi 29 (1972), str. 289. sqq.

24. Feenstra, R., Grotius' Doctrine of Unjust Enrichment as a Source of Obligation: Its Origin and Its Influence in Roman-Dutch Law, u: Schrage, E. (ur.), Unjust Enrichment, Berlin, 1999., str. 197. sqq.

25. Fercia, R., "Quia vendidit, dare promisit", Cagliari, 2009.

26. Fleischhacker, J., Institutiones juris hungarici 2, Bratislava, 1795.

27. Gallo, P., Unjust Enrichment: A Comparative Analysis, The American Journal of Comparative Law 40, 2 (1992), str. 431. sqq.

28. Giglio, F., La actio de in rem verso nel sistema del codice civile, Rivista di diritto civile 46, 2 (2000), str. 249. sqq.

29. Giglio, F., A Systematic Approach to "Unjust" and "Unjustified" Enrichment, Oxford Journal of Legal Studies 23, 3 (2003), str. 455. sqq. 
30. Giorgianni, M., Causa del negozio giuridico (diritto romano), u: Moratti, C.; Pugliatti, S. (ur.), Enciclopedia del diritto 6, Milano, 1969., str. 547. sqq.

31. Gomes, J., Unjust Enrichment: a Few Comparative Remarks, European Review of Private Law 9, 2 i 3 (2001), str. 449. sqq.

32. Grauer, F., Die ungerechtfertigte Bereicherung im französischen Privatrecht, Heidelberg, 1930.

33. Hagen, O., Die condictio ob turpem causam im gemeinen Rechte und Bürgerlichen Gesetzbuche, Leipzig, 1913.

34. Hallebeek, J., Developments in Mediaeval Law, u: Schrage, E. (ur.), Unjust Enrichment, Berlin 1999., str. 59. sqq.

35. Hallebeek, J., Some remarks concerning the so-called Condictio Iuventiana (D. 12, 1, 32), Revue internationale des droits de l'antiquite, $3^{\text {e }}$ série, tome 32 (1985), str. 24. sqq.

36. Hallebeek, J., The condiction as enrichment action in twelfth and thirteenth century legal scholarship, Tijdschrift voor Rechtsgeschiedenis 63 (1995), str. 263. sqq.

37. Hallebeek, J., Unjust enrichment as a source of obligation. The genesis of a legal concept in the European ius commune, Restitution Law Review 10 (2002), str. 92. sqq.

38. Hartkamp, A. S., Unjust Enrichment alongside Contracts and Torts, u: Schrage, E. (ur.), Unjust Enrichment, Berlin, 1999., str. 25. sqq.

39. Hedley, S., Unjust Enrichment, Cambridge Law Journal 54, 3 (1995), str. 578. sqq.

40. Hedley, S., "Unjust" at Common Law: So Many Concepts, So Little Clarity, European Review of Private Law 14, 3 (2006), str. 399. sqq.

41. Heemann, M., Action for money had and received, Berlin, 1996.

42. Held, H.-R., Kondikcijski i verzijski zahtjevi de iure condito, Pravo u gospodarstvu 54, 6 (2015), str. 1343. sqq.

43. Held, H.-R., Neki problemi suvremenog uređenja stjecanja bez osnove, Hrvatska pravna revija 13 (2015), str. 13. sqq.

44. Held, H.-R., Podrijetlo postupka legis actio per condictionem, Zbornik Pravnog fakulteta u Zagrebu 67, 2 (2017), str. 197. sqq.

45. Heymann, E., Das ungarische Privatrecht und der Rechtsausgleich mit Ungarn, Tübingen, 1917.

46. Huszty, S., Juriprudentia practica, lib. II, Eger, 1745.

47. Ibbetson, D., Unjust Enrichment in England before 1600, u: Schrage, E. (ur.), Unjust Enrichment, Berlin, 1999., str. 121. sqq.

48. Ibbetson, D., Unjust Enrichment in English Law, u: Schrage, E. (ur.), Unjust Enrichment and the Law of Contract, London, 2001., str. 33. sqq.

49. Jesensky, A.; Protić, P., Privatno pravo u Vojvodini, Sombor, 1922.

50. Jung, J. von, Darstellung des ungarischen Rechts, Beč, 1827.

51. Kantorowicz, H.; Buckland, W., Studies in the Glossators of Roman Law, Aalen, 1969.

52. Kapor, V., Condictiones sine causa $i$ actio de in rem verso $i$ moderno pravo, Zbornik Pravnog fakulteta u Zagrebu 1 (1969), str. 5. sqq.

53. Kelemen, I., Institutiones juris privati hungarici 2/2, Pešta, 1814.

54. Korporowicz, Ł. J., Roman Law in Roman Britain: An Introductory Survey, The Journal of Legal History 33, 2 (2012), str. 133. sqq.

55. Kövy, S., Elementa jurisprudentiae hungaricae, Košice, 1807. 
56. Krebs, T., In defence of unjust factors, u: Johnston, D.; Zimmerman, R. (ur.), Unjustified Enrichment, Cambridge, 2004., str. 76. sqq.

57. Kupisch, B., Die Versionsklage, Heidelberg, 1965.

58. Kupisch, B., Ungerechtfertigte Bereicherung, Heidelberg, 1987.

59. Kupisch, B., Ungerechtfertigte Bereicherung. Usus modernus pandectarum in Deutschland unter Berücksichtigung des preußischen Allgemeinen Landrechts (ALR) und des österreichischen Allgemeinen bürgerlichen Gesetzbuchs (ABGB), u: Schrage, E. (ur.), Unjust Enrichment, Berlin, 1999., str. 237. sqq.

60. Lanović, M., Privatno pravo Tripartita, Zagreb, 1929.

61. Leyser, A., Meditationes ad Pandectas 2, Leipzig, 1774.

62. Leyser, A., Meditationes ad Pandectas 3-4, Leipzig, 1776.

63. Eętowska, E., Unjust Enrichment in Eastern European Countries, u: Caemmerer, E. von; Schlechtriem, P. (ur.), International Encyclopedia of Comparative Law 10, Tübingen, 2007., poglavlje 4, str. 3. sqq.

64. Martinek, M., Der Weg des Common Law zur allgemeinen Bereicherungsklage. Ein später Sieg des Pomponius?, Rabels Zeitschrift für ausländisches und internationales Privatrecht 47 (1983), str. 284. sqq.

65. Meier, S., Unjust factors and legal grounds, u: Johnston, D.; Zimmerman, R. (ur.), Unjustified Enrichment, Cambridge, 2004., str. 37. sqq.

66. Meier, S., Unjustified Enrichment, u: Basedow, J. et al. (ur.), The Max Planck Encyclopedia of European Private Law 2, Oxford, 2012., str. 1742. sqq.

67. Miladin, P., Običaji, kondikcije, ortaštvo i ugovorna kazna prema Bogišićevu Općem imovinskom zakoniku za Crnu Goru (OIZ) i hrvatskom Zakonu o obveznim odnosima (ZOO), u: Kregar, J. et al. (ur.), Bogišić i kultura sjećanja, Zagreb, 2008.-2011., str. 66. sqq.

68. Miladin, P.; Markovinović, H., Obogaćenje kao pretpostavka neopravdanog obogaćenja (stjecanja bez osnove), Zbornik Pravnog fakulteta u Zagrebu 68, 1 (2018), str. 5. sqq.

69. Mugdan, B., Die gesammten Materialien zum Bürgerlichen Gesetzbuch für das Deutsche Reich 2, Berlin, 1899.

70. Nikšić, S., Kauza obveze i srodni instituti u poredbenom pravu, Zbornik Pravnog fakulteta u Zagrebu 56, 4 (2006), str. 1057. sqq.

71. Obiwulu, A., Tractatus de legibus in 13th Century Scholasticism, Münster, 2003.

72. Palmer, G., History of Restitution in Anglo-American Law, u: Caemmerer, E. von; Schlechtriem, P. (ur.), International Encyclopedia of Comparative Law 10, Tübingen, 2007., poglavlje 3, str. 3. sqq.

73. Péter, L., The Irrepressible Authority of the Tripartitum, u: Bak, J. et al. (ur.), Decreta regni mediaevalis Hungariae 5: Tripartitum opus iuris consuetudinarii inclyti regni Hungariae per Stephanum de Werbewcz editum, Budimpešta, 2005., str. xiii. sqq.

74. Petrak, M., Rimsko pravo kao pozitivno pravo u Republici Hrvatskoj. Prilog tumačenju Zakona o načinu primjene pravnih propisa donesenih prije 6. travnja 1941. godine, Hrvatska pravna revija 10 (2006), str. 1. sqq.

75. Petrak, M., Inter aequitatem iusque interpositam interpretationem nobis solis et oportet et licet inspicere. Konstantinovo shvaćanje pravednosti u suprotnosti s klasičnim rimskim pravom, Latina et graeca, nova serija 24 (2014), str. 39. sqq.

76. Piškulić, Z.; Džerdž, I., Osnovi privatnoga prava u Vojvodini, Beograd, 1924.

77. Radovčić, V., Pokušaj kodifikacije građanskog prava u staroj Jugoslaviji ("Predosnova građanskog zakonika za kraljevinu Jugoslaviju"), Radovi Zavoda za hrvatsku povijest 7, 1 (1975), str. 249. sqq.

78. Rady, M., Stephen Werböczy and his Tripartitum, u: Bak, J. et al. (ur.), Decreta regni mediaevalis Hungariae 5: Tripartitum opus iuris consuetudinarii inclyti regni Hungariae per Stephanum de Werbewcz editum, Budimpešta, 2005., str. xxvii. sqq. 
79. Rambaud-Buhot, J., Gratian, Decretum of (Concordia discordantium canonum), u: Halfmann, J. (ur.), New Catholic Encyclopedia 6, Detroit, 2003., str. 420.-422.

80. Ranieri, F., Europäisches Obligationenrecht, Beč, 2009.

81. Savigny, F. von, System des heutigen römischen Rechts 5, Berlin, 1841.

82. Schäfer, F., Das Bereicherungsrecht in Europa, Berlin, 2001.

83. Schartl, R., Ungerechtfertigte Bereicherung nach deutschen Rechtsquellen des Mittelalters, Tijdschrift voor Rechtsgeschiedenis 60 (1992), str. 109. sqq.

84. Schlechtriem, P.; Coen, C.; Hornung, R., Restitution and Unjust Enrichment in Europe, European Review of Private Law 9, 2 i 3 (2001), str. 377. sqq.

85. Schlesinger, P., Arricchimento, Azione di (diritto civile), u: Azara, A.; Eula, E. (ur.), Novissimo Digesto Italiano 1/2, Torino, 1958., str. 1004. sqq.

86. Schrage, E., The Law of Restitution: The History of Dutch Legislation, u: Schrage, E. (ur.), Unjust Enrichment, Berlin, 1999., str. 323. sqq.

87. Schrage, E., Unjustified enrichment. Recent Dutch developments from a comparative and historical perspective, Netherlands International Law Review 46, 1 (1999), str. 57. sqq.

88. Schrage, E.; Barry, N., Unjust Enrichment and the Law of Restitution: A Comparison, u: Schrage, E. (ur.), Unjust Enrichment, Berlin, 1999., str. 9. sqq.

89. Schulz, F., Prinzipien des römischen Rechts, Berlin, 2003.

90. Scozzafava, O. T., La proprietà, u: Lipari, N. et al. (ur.), Diritto civile 2/2, Milano, 2009., str. 61. sqq.

91. Singer, J.; Svoboda, M., Privatno pravo u Vojvodini i Medimurju, Zagreb, 1926.

92. Sirena, P., L'azione generale di arricchimento senza causa, u: Lipari, N. et al. (ur.), Diritto civile 3/1, Milano, 2009., str. 554. sqq.

93. Snijders, W., From Pomponius to Article 6:212 Dutch Civil Code-The Vicissitudes of a Tradition, European Review of Private Law 14, 3 (2006), str. 391. sqq.

94. Swoboda, E., Natur und Inhalt des Bereicherungsanspruches im österreichischen Recht, Beč, 1916.

95. Webb, C., What is Unjust Enrichment?, Oxford Journal of Legal Studies 29, 2 (2009), str. 215. sqq.

96. Wesener, G., Zur Bedeutung des Usus modernus pandectarum für das österreichische ABGB, u: Harrer, F. et al. (ur.), Gedächtnisschrift für Theo Mayer-Maly, Beč, 2011., str. 571. sqq.

97. Winkler, J. F., Roman Law in Anglo-Saxon England, The Journal of Legal History 13, 2 (1992), str. 101. sqq.

98. Wollschläger, C., Das stoische Bereicherungsverbot in der römischen Rechtswissenschaft, u: Behrends, O. et al. (ur.), Römisches Recht in der europäischen Tradition, Ebelsbach, 1985., str. 41. sqq.

99. Zachariä, K. S., Handbuch des Französischen Civilirechts 1-3, Heidelberg, 1808.-1827.

100. Zimmerman, R., The Law of Obligations, Cape Town, 1992.

101. Zimmerman, R., Unjustified Enrichment: The Modern Civilian Approach, Oxford Journal of Legal Studies 15, 3 (1995), str. 403. sqq. 
Henrik-Riko Held*

\section{DEVELOPMENT OF THE UNJUSTIFIED ENRICHMENT IN THE RECEPTION OF ROMAN LAW**}

\section{Summary}

The author in this article analyses the development of the unjustified (unjust) enrichment as a general and an independent source of obligations on the basis of Roman law. Although such a concept admittedly did not exist in Roman law, certain actions therefrom were largely used in the formative period of the civil and canon law scholarship in the Middle Ages, as well as in the subsequent reception of Roman law at the courts in continental Europe. On that basis contemporary theoretical analyses and case law often use Roman legal terminology in the context of unjustified enrichment (condictio and diferent condictiones, actio de in rem verso, etc.). The aim of this analysis is to propose a contribution to a more complete and a more accurate appreciation of the connection between actions from Roman law and the formation of the concept of unjustified enrichment, and with that also their connection and relevance in a contemporary context. Accordingly, the general development in the Middle Ages is the first part of the analysis, followed by two basic different tendencies in the development. One of them is associated with the French law, where Roman actio de in rem verso had an important role in the development of the unjustified enrichment law. The other is related to the German law, which is in this respect based on Roman condictiones. Besides, the English common law and the historical Hungarian private law, or the private law of the Tripartitum in its application in the Kingdom of SHS, or the Kingdom of Yugoslavia, are also analysed as examples of the systems originally unrelated to Roman law in this regard, but experiencing strong influence later on, principally by means of systems more strongly shaped on the basis of Roman condictiones. Conclusive remarks discuss the general presence of Roman law in the development of unjustified enrichment law and in its contemporary variants, as well as the optimality of the systems more authentically based on Roman legal sources.

Keywords: $\quad$ unjustified enrichment, unjust enrichment, condictio, actio de in rem verso, Roman law, reception of Roman law

\section{(c) (i) (3)}

This work is licensed under a Creative Commons

Attribution-NonCommercial 4.0 International License.

* Henrik-Riko Held, PhD, Assistant Professor, Faculty of Law, University of Zagreb, Republike Hrvatske Square 14, Zagreb, Republic of Croatia. Email address: hheld@pravo.hr. ORCID ID: orcid.org/0000-0002-6217-2655.

** This paper is a result of a scientific project of the University of Zagreb, Faculty of Law, titled The New Croatian Legal System. 